\title{
Investigation of the Effect of Traffic Noise in Inspection of Urban-Level Noise: A Noise Analysis in Konya - Nalcaci Street
}

\author{
By Zeynep Ümmühatun Özen ${ }^{*}$, Mustafa Tosun ${ }^{ \pm}$\& Enes Yasa
}

In this study, the effects of noise, due to the increase in population in urban centers, industrialization and land traffic, are evaluated on human health, indoor life standards, and auditory comfort. For this purpose, noise levels were recorded in Ahmet Hilmi Nalcaci Street, which is one of the densest streets of Konya. The recordings were performed at 14 different stations, three times a day and for 14 days. A "Testo 815" brand device was used for measurement and recording. The results of the measurements were evaluated according to international standards and domestic regulations, taking into account the situations where windows and doors, which constitute integrity and blanks in the envelope of a structure, are open. It was determined that the noise levels recorded at the stations are above the discomfort threshold. Settlement-and architecture-level measures to reduce and control noise are suggested in the study. It was determined that the most effective measure in this context would be isolation in structure envelopes. Types of walls generally used in the buildings around the street, which is the subject of the study, were determined and the sound penetration loss values for these walls were given. The sound penetration loss values were also compared to indoor noise limit values in certain measurement points and excessive noise values were presented in the study.

Keywords: Noise pollution, traffic noise control, environmental noise, urban level noise, Testo 815

\section{Introduction}

Noise has become one of the most important problems of our age and while it doesn't have a specific structure, it is defined as "unpleasant sound which is a source of danger for humans" or "polluted version of natural sounds". Noise is not defined by the quality of sound, it depends on our reaction to the sound.

Exemplified as all kinds of sounds that are disturbing, annoying, or that which hampers daily activities such as working, resting, and entertaining, noise includes all sounds that have high intensity, that are unpleasant or unexpected (Doelle 1972). Sources of noise can be classified into various perspectives. Noises, which can generate or spread in the air or solid environments based on the source of the sound, can spread from point, linear, or planar sources (Kurra 1997).

The effect of noise on humans varies among persons and societies (Akgüngör and Demirel 2003). The negative effects of noise on humans start at 55-60 dB.

\footnotetext{
*Researcher and Graduate Student, Konya Technical University, Turkey.

${ }^{ \pm}$Professor, Konya Technical University, Turkey.

*Associate Professor, Istanbul University, Turkey.
} 
The disturbances at these levels are noticeably increased by the noise level reaching $60-65 \mathrm{~dB}$. If the noise level is above $65 \mathrm{~dB}$, there are serious physical, psychological, physiological, and performance impacts on the person (OECD 1986).

Noise control is all controls and measures applied to minimize sounds of any origin, which are in the form of noise, and negative effects of these sounds, and also preserve user welfare and a productive environment for people. All of the methods such as changing the acoustics of the voice to provide a certain background noise level in the interior, reducing the duration of the effect, lowering it to an acceptable level, masking it with another voice that sounds pleasant or less disturbing are defined as noise control (Kurra 2009).

There have been many studies on ambient noise and its effects in the world and Turkey. Ho, et al. examined the effects of road coverage and tire deterioration on tire/road noise in their work (Ho et al. 2013). Freitas et al. investigated the effect of different road types, vehicle speeds, and traffic intensity on traffic noise in their work (Freitas et al. 2012). Praticòa and Lédéeb (2012) have studied the use of coatings to reduce traffic noise in their work (Praticòa and Lédéeb 2012). Ko et al. (2011) used a case study to assess noise impact in Chungju, Korea using CBS and noise maps (Ko et al. 2011). Naish (2010) created a noise management strategy for Australia's seven different local governments. In the study, the data presented in GIS format and the six-step method of traffic noise calculation were used (Naish 2010). Özyonar and Peker (2008) investigated the ambient noise pollution in Sivas city center (Özyonar and Peker 2008). Cho and Mun (2008) investigated the effects of surface coating types on vehicle noise to evaluate various road surface types by the Korean Highway Corporation (Cho and Mun 2006, 2008). Ledee and Pichaud (2007), in a study conducted in 2007, the tire/road noise to Have examined the effect of temperature. Tire/road noise when outdoor temperature increases emissions are reduced (about $0.1 \mathrm{~dB} / 1^{\circ} \mathrm{C}$ ) (Lede and Pichaud 2007). Qadis and Alhory (2007) developed three models that predicted these parameters by analyzing the parameters affecting road traffic noise (vehicle type, road surface characteristics, horn usage status, vehicle speed, road width, etc.) (Qadis and Alhory 2007). Zannin et al. (2006), conducted noise measurements at 303 different locations in six city parks in Crubita, Brazil, and determined noise pollution classes of these parks according to the noise limit allowed by local law (Zannin et al. 2006). Nas and Berktay (2004) identified 189 points in intersections and main roads where traffic was concentrated, covering an area of $120 \mathrm{~km}^{2}$ to prepare a noise pollution map in the Konya Town residential area where this study area is located and the maximum noise level (Lmax) and the equivalent noise level (Leq) (Nas and Berktay 2004, Özyonar and Peker 2008). Güremen and Çelik (2003) aimed to determine the noise levels of the individuals living in these regions and the effects of noise on various actions within the periods of the study of traffic noise levels and determination of traffic conditions at the 61 reference points on the main roads and junctions in 11 regions specified in Niğde (Güremen and Çelik 2003). Tang and Tong (2003) developed a new model, examining previous models for traffic noise forecasting for sloping roads in free-flow traffic conditions (Tang and Tong 2003). Li et al. (2001) were able to predict the traffic 
noise value with the help of a GIS-based model, which was included in all the factors affecting the traffic noise (Li et al. 2001).

Harris et al. (2000) compared the traffic noise model with the Stamina model over noise measurements (Harris and et al. 2000). Wetzel et al. (1999) stated that in Germany there are many standards for modeling roadside noise propagation (Ko et al. 2011, Sandberg 2003). Bay and Güney (1998) performed a study on tireroad noise. In the result of the work done, it was seen that as the speed increases at all loads and measurement positions, the noise level increases significantly, with the highest noise level at all loads and speeds being at the front of the tire and the lowest noise level at the side. As the load is reduced at the front, the noise level is also reduced to a degree, and at higher speeds, it is observed that the difference is smaller (Bay and Guney 1998). Kurra (1991) studied the environmental problems in Istanbul and possible solutions for these problems. In his research, 13 sample zones were selected to portray the noise conditions affecting households in every region, and the effects of this noise (Kurra 1991).

\section{Evaluating Ambient Noise}

The negative effects of noise on human health, behavior, and effectiveness have been portrayed in many studies until our day. Increasing noise due to technological progress and population increase affects people at different rates according to situations and conditions within buildings, and the consequences of this influence can sometimes lead to serious problems. The European Commission has set some targets for the average environmental impact to be below 65 LAeq, never exceeding 85 LAeq, and not hanging 55 LAEQs in quiet areas, under the "Fifth Environment Action Program" launched in 1996. Towards this goal, the EU member states have accelerated their ongoing work on noise control and have established common guidelines for noise mapping and noise mapping for all settlements (EU Green Paper 1996).

Noise maps, which can be defined in the form of a plan, or a section, of acoustic information belonging to a specific region or a city, in detail, in the same system, with equal level curves, coloring system and/or numerical value, city, contain a lot of information that can be used in planning stages. In many developed countries, preparation of regional and provincial scale noise maps are attached much importance and while reporting the current situation with the help of said maps, other studies are performed to examine the changes to be caused by possible developments. Germany, France, Greece, Holland, Denmark, Portugal, Spain, The UK, and Sweden are among the countries where advanced studies were performed on noise maps while in Turkey there are quite a few studies in this area. Therefore it is not yet possible to evaluate noise maps within the framework of city information systems and make use of the planning decree (Demirkale 1996, Kurra 2000). 


\section{National Directive - Directive on Evaluation and Management of Ambient Noise}

In the Directive on Evaluation and Management of Ambient Noise, which is in effect in Turkey, the articles related to maximum levels for noise generated from transportation and industry, are stated below (Table 1). Ambient noise criteria for highways; Article 18 - (1) Values regarding the level of ambient noise generating from highways and prevention of highway noise cannot surpass the limit values presented in Table 6; and values regarding light rail systems cannot surpass the limit values presented in Table 7 (Resmi Gazete 2008).

Table 1. Highway Environmental Noise Limit Values

\begin{tabular}{|c|c|c|c|c|c|c|}
\hline \multirow{2}{*}{ Areas } & \multicolumn{3}{|c|}{$\begin{array}{c}\text { Planned/Renewed/Repaired } \\
\text { Roads }\end{array}$} & \multicolumn{3}{|c|}{ Existent Roads } \\
\hline & $\begin{array}{l}\mathbf{L}_{\text {guindizi }} \\
(\text { dBA })\end{array}$ & $\begin{array}{l}\mathbf{L}_{\text {aksam }} \\
(\text { dBA })\end{array}$ & $\begin{array}{c}\mathbf{L}_{\text {gece }} \\
(\mathbf{d B A})\end{array}$ & $\begin{array}{l}\mathbf{L}_{\text {guindiuz }} \\
(\mathbf{d B A}) \\
\end{array}$ & $\begin{array}{l}\mathbf{L}_{\text {akşam }} \\
(\mathbf{d B A}) \\
\end{array}$ & $\begin{array}{r}\mathbf{L}_{\text {gece }} \\
(\mathbf{d B A})\end{array}$ \\
\hline $\begin{array}{l}\text { Noise-sensitive uses } \\
\text { such as education, } \\
\text { cultural activities, health } \\
\text { facilities, summer } \\
\text { houses and camping } \\
\text { sites }\end{array}$ & 60 & 55 & 50 & 65 & 60 & 55 \\
\hline $\begin{array}{l}\text { Household-sensitive } \\
\text { areas in the areas where } \\
\text { there are commercial } \\
\text { buildings and noise- } \\
\text { sensitive usages }\end{array}$ & 63 & 58 & 53 & 68 & 63 & 58 \\
\hline $\begin{array}{l}\text { Commercial places in } \\
\text { the areas where there } \\
\text { are commercial } \\
\text { buildings and noise- } \\
\text { sensitive usages }\end{array}$ & 65 & 60 & 55 & 70 & 65 & 60 \\
\hline Industrial areas & 67 & 62 & 57 & 72 & 67 & 62 \\
\hline
\end{tabular}

Source: Kurra et al. 1993.

Where the light rail system passes underground, the maximum resonance time at $500 \mathrm{~Hz}$ should be 1.4 for the project target and 1.6 seconds for the acceptance while the station is empty (Table 2). Effective and feasible measures are taken taking into consideration the techniques of noise curtaining in places where light rail transportation system inside and outside the city passes through noise-sensitive areas (Resmi Gazete 2008). 
Table 2. Environmental Noise Limit Values for Light Rail Systems

\begin{tabular}{|c|c|c|c|c|c|}
\hline \multicolumn{2}{|c|}{ Underground Stations } & $\begin{array}{c}\text { Leg } \\
(\text { dBA })\end{array}$ & \multicolumn{2}{|c|}{ Above ground Stations } & $\begin{array}{c}\text { Leg } \\
(\text { dBA })\end{array}$ \\
\hline \multicolumn{2}{|c|}{ Cashdesks, stairs, corridors } & 55 & \multirow{7}{*}{$\begin{array}{c}\text { Platforms } \\
\text { (1.8 m from } \\
\text { platform edge) }\end{array}$} & $\begin{array}{l}\text { For trains } \\
\text { stopping } \\
\text { and } \\
\text { launching }\end{array}$ & 70 \\
\hline \multirow{3}{*}{$\begin{array}{l}\text { Platforms } \\
\text { (1.8 m from } \\
\text { platform } \\
\text { edge) }\end{array}$} & $\begin{array}{l}\text { For trains } \\
\text { stopping and } \\
\text { launching }\end{array}$ & 80 & & \multirow{3}{*}{$\begin{array}{l}\text { Passing } \\
\text { trains }\end{array}$} & \multirow{3}{*}{75} \\
\hline & Passing trains & 85 & & & \\
\hline & $\begin{array}{l}\text { Trains } \\
\text { standing by in } \\
\text { working } \\
\text { condition }\end{array}$ & 65 & & & \\
\hline \multicolumn{2}{|c|}{$\begin{array}{l}\text { In-station air conditioning } \\
\text { system }\end{array}$} & 55 & & \multirow{3}{*}{$\begin{array}{l}\text { Trains } \\
\text { standing by } \\
\text { in working } \\
\text { condition }\end{array}$} & \multirow{3}{*}{65} \\
\hline \multicolumn{2}{|c|}{ Ventilation chan } & 55 & & & \\
\hline \multicolumn{2}{|c|}{$\begin{array}{l}\text { Emergency ventilation fans in } \\
\text { close volumes in stations (at } \\
22.5 \mathrm{~m} \text { ) }\end{array}$} & 80 & & & \\
\hline
\end{tabular}

Source: Resmi Gazete 2008.

\section{Noise Exposure Categories}

Article 27 - (1) In planning station, below noise exposure categories are considered in the determination of suitable areas (Resmi Gazete 2008):

A) Category A ( $<55 \mathrm{dBA}$ in Ldaytime) Area: In planning decisions, precautions are taken to preserve present silence while taking into consideration, present or planned uses that are very sensitive to noise. The noise at the top level of this category is not at the discomfort level.

B) Category B (55-64 dBA in Ldaytime) Area: The background noise level should be taken into account when planning permission is given to protect frequent and modest uses. Measures against noise are taken when necessary.

C) Category C (64-74 dBA in Ldaytime) Area: Planning decision is not normally given. However, in cases where the public interest is necessary, if there is a need to permit due to the absence of a quieter place, measures against noise are taken while considering the background noise level.

D) Category D (>74 dBA in Ldaytime) Area: No planning decision is made. The situation is examined in terms of noise-immune uses and permission can be given if the buildings can be arranged in such a way to block noise (Resmi Gazete 2008). 
Noise Indicators Used in Noise Maps

Day-Evening-Night Level $\mathrm{L}_{\mathrm{gag}}\left(\mathrm{L}_{\mathrm{den}}\right)$ : Expression of daytime-evening-night levels through the formula given below (Resmi Gazete 2008).

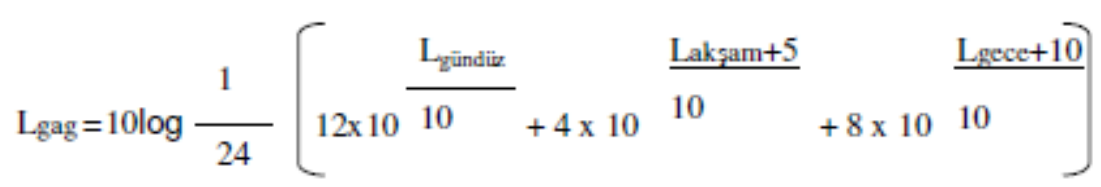

In the formula, as defined in TS 9798 (ISO 1996-2), $\mathrm{L}_{\text {daytime }}(\mathrm{Ld})$ is the energy average of weighted long-term sound level and it is determined based on the year's daytime periods.

Levening (Le), as defined in TS 9798 (ISO 1996-2), is the energy average of weighted long-term sound level and it is determined based on the year's evening periods.

$\mathrm{L}_{\text {night }}$ (Ln), as defined in TS 9798 (ISO 1996-2), is the energy average of weighted long-term sound level and it is determined based on the year's night periods.

In the formula:

Daytime: 12 hours, including from 07:00 until 19:00.

Evening: 4 hours, including from 19:00 until 23:00.

Night: 8 hours, including from 23:00 until 07:00.

\section{Highway Traffic Noise}

Road noise caused by traffic is the type of noise most people are exposed to and most disturbed by. The fluctuations in the intensity of the noise during the day are seen, but the inconvenience caused by the continuous noise is quite excessive. Road transport from traffic noise, which can be considered a point source of sound in a variety of vehicles on the roads is an integrated power noise generated during their motion in the same moment and research has shown that $80 \%$ of the sound energy generated in urban residential areas are caused by traffic noise $80 \%$ of the sound energy generated in urban residential areas comes from traffic (Kurra et al. 1993, Pakman 1990).

The noise level in roadway noise measurements goes up to $105 \mathrm{dBA}$ at a 7.5 $\mathrm{m}$ distance from the roadside. These values are above the comfort standards of people (Beranek 1974, Alexandre 1975). The main factors of the vehicle transportation noise generated by the operation of the vehicles and the result of the movements are noise from braking, noise from the contact of the wheels with the road surface, and aerodynamic noise caused by the vehicle. Factors affecting the level of noise perception on the road are; distance to the road, traffic volume, road level, type of road cover, the grade of road slope, size and type of vehicle, roadside restoration, and vegetation cover. 
Traffic density, traffic composition (light and heavy vehicles percent), the type of traffic flow (batch or continuous flow), average speed, the type of the road coating, the slope of the road, curves and intersections on the road, the size of the engine, the vehicle's age, road width and retaining walls are factors that can be counted among reasons affecting noise levels in highways (Akgüngör and Demirel 2003).

As the number of vehicles increases, the transportation noise increases. Increasing traffic intensity on a road causes the noise level to increase logarithmically. For example, when a single-vehicle causes $64 \mathrm{~dB}$ of noise, 2000 vehicles per hour generate $66 \mathrm{~dB}$ and 6000 vehicles generate $71 \mathrm{~dB}$ of noise (Can et al. 2000).

On the other hand, the noise level varies according to the types of traffic vehicles. Noise caused by heavy vehicles, especially trucks, is more than other vehicles. One reason for this is the axle loads that they bear. In heavy vehicles, when axle load decreases from $2000 \mathrm{~kg}$ to $500 \mathrm{~kg}$, the noise caused also reduces by $15 \mathrm{~dB}$.

Also increasing vehicle speeds increase the noise generated. The reason for this is that at high speeds, the rubbing of the vehicle wheels with the road surface is more severe than motor noise. However, this noise increase due to speed is not significant in trucks. The noise levels caused by vehicle speed and type can also be calculated using a variety of empirical formulae.

\section{Factors Affecting Traffic Noise}

The noise originating from the traffic depends on the distance between the traffic (source) and the receiver, the land cover between the source and the receiver, the type of road cover on which the source moves, the meteorological conditions of the region, the traffic density in the region, the traffic composition of the road, noise suppressing and reflecting structures between the source and the receiver, traffic speed at the region, road slope, etc. For example, a $10^{\circ} \mathrm{C}$ temperature increase in a region examined for traffic noise results in a reduction in the noise level of about $1 \mathrm{dBA}$. Thus if the noise originating from road transport needs to be examined, full knowledge is needed on the factors above (EAPA 2007).

\section{Components of Noise in Motor Vehicles}

Passing vehicles generate noise due to many factors and these factors can be separated into three main groups, namely aerodynamic structure (wind-turbulence), vehicle motor and units, and tires/road. Aerodynamic noise is defined as the noise emission that occurs in the order of the turbulent airflow that occurs partially on the vehicle periphery during the movement of the vehicle. At low and medium speeds, this type of noise is often not a significant factor for off-road vehicles. The noise generated in the vehicle's engine and connected units comes from the engine, the drive system, the fan, the exhaust, and the transmission system. The third group is the noise generated during the rotation of the tires on the road surface 
(Sandberg 2002). The noise components on the road and their different graphical values, the speed-dependent relationship, and changes of the heavy (intermittent) and light vehicles (permanent) wheel, motor, and total noises are given in Figure 1.

The effect of tire/road noise is increased within overall noise emission by vehicle acceleration. Noise from the car's engine is an important factor in urban roads where speed limits are around $30-50 \mathrm{~km} / \mathrm{h}$, while noise is ignored on intercity highways and motorways. Vehicle categories also have an important influence on noise levels. The sound pressure level of a passing vehicle increases along with the approach of the vehicle, reaching the peak point at the closest proximity. As you move away from the nearest point of approach, the sound pressure level decreases.

Figure 1. Examples of Road Noise Graphs



(a)



(b)

Frequency $(\mathrm{Hz})$

Source: Sandberg 2003.

Velocity[kmH]

(a) Frequency spectrum of the noise generated by 50 different cars during their course at $90 \mathrm{~km} / \mathrm{h}$ on a straight road (ISO 10844).

(b)Speed-dependent level graphics of heavy (batch) and light (continuous) vehicles' tire, engine, and total noises.

Figure 1 contains various example graphics in connection to the relations which affect highway transportation noise. Figure 1a, which consists of two separate graphics, exhibits the frequency spectra of 50 vehicles, which are moving at $90 \mathrm{~km} / \mathrm{h}$ speed on an arbitrarily constructed straight road at ISO 10844 properties. In graphic $1 \mathrm{~b}$, tire and engine noises of heavy and light vehicles can be observed together with levels of total noise produced by a vehicle in terms of speed.

\section{Materials and Methods}

In literature, methods such as "Building Research Establishment (Bre) Methods, Department of Environment (Doe), Cetur Method, Canada Mortgage and Housing Corporation (Cmhc), National Cooperative Highway Research 
Program Report: The UK Method (CoRTN Procedure) German Method; Rls 90, Italian Method; Crn, Fhwa Method, Nmpb Routes 96" are used in relation to ambient noise calculation technics, highway noise prediction methods, and highway traffic noise calculation guides.

This study uses a calibrated Testo 815 brand noise level measurement device for respective noise level measurements. The device can pick up noise levels between 32-130 dBA. View of the measuring device is given in Figure 2, the specifications are given in Table 3 .

Table 3. Specifications of the Testo 815 Manual Noise Measurement Device

\begin{tabular}{|l|c|}
\hline Measurement range & $+32 \ldots+130 \mathrm{~dB}$ \\
\hline Frequency range & $31,5 \mathrm{~Hz} \ldots 8 \mathrm{kHz}$ \\
\hline Accuracy \pm 1 digit & $\pm 1.0 \mathrm{~dB}$ \\
\hline Resolution & $0.1 \mathrm{~dB}$ \\
\hline Operating temperature & $+40^{\circ} \mathrm{C}$ \\
\hline Storage temperature & $-10 \ldots+60{ }^{\circ} \mathrm{C}$ \\
\hline Battery type & $9 \mathrm{~V}$ block battery \\
\hline Battery life & $70 \mathrm{~h}$ \\
\hline Weight & $195 \mathrm{~g}$ \\
\hline Dimensions & $255 \times 55 \times 43 \mathrm{~mm}$ \\
\hline Partial measurement ranges & $30 \ldots 80 \mathrm{~dB} ; 50 \ldots 100 \mathrm{~dB} ; 80 \ldots 130 \mathrm{~dB}$ \\
\hline Time settings & Fast $125 \mathrm{~ms} / \mathrm{Slow}$ \\
\hline
\end{tabular}

Figure 2. View of the Testo 815 Noise Measurement Device



\section{Choice of the Work Area}

Studies in Konya have shown that noise generated from the traffic is at high levels (Aydin 2004). As can be understood from the number of vehicles passing between 07:00-19:00, presented in Table 4, the facts that it is the street with the most vehicles, there are mostly noise-sensitive household and commercial buildings in both sides of the street and it interconnects the north and south parts, that is, main accommodation and industrial zones, of the city, make Ahmet Hilmi Nalcaci Street one of the most suitable places to study (Figure 3). 
Figure 3. View from Nalcaci Street


Table 4. Traffic Dispersion and Highway Properties in Konya's Main Streets, according to Hourly Periods in 2013

\begin{tabular}{|l|c|c|c|c|c|c|}
\hline Queue No & Street Name & Class & $\begin{array}{c}\text { For 07:00-19:00 } \\
\text { Period } \\
\text { unit }\end{array}$ & $\begin{array}{c}\text { All Road } \\
\text { Span }\end{array}$ & $\begin{array}{c}\text { Single Road } \\
\text { Span (m) }\end{array}$ & $\begin{array}{c}\text { Total } \\
\text { Number } \\
\text { of Lanes }\end{array}$ \\
\hline 1 & Adana Çevre Yolu St & A & 54,957 & 59.06 & 27.78 & 6 \\
\hline 2 & Beyşehir St & A & 32,911 & 26.50 & 10.50 & 6 \\
\hline 3 & Karaman St & A & 29,559 & 14.40 & 7.20 & 4 \\
\hline 4 & Yeni Sille St & A & 32,911 & 43.00 & 20.00 & 4 \\
\hline 5 & Rauf Denktaş St & A & 35,357 & 20.00 & 9.00 & 6 \\
\hline 6 & Hilmi Nalcaci St & A & 69,928 & 28.70 & 9.60 & 6 \\
\hline
\end{tabular}

Source: Konya Metropolitan Municipality 2013.

The area of the study zone is approximately 16 sqm and its length is $2.1 \mathrm{~km}$. According to the information taken from Konya Metropolitan Municipality, road features of Nalcaci Street are given in Table 5.

Table 5. Road Characteristics of the Study Area

\begin{tabular}{|l|c|}
\hline All road span & $28.70 \mathrm{~m}$ \\
\hline Single Road Span & $9.60 \mathrm{~m}$ \\
\hline Total number of lanes & 6 \\
\hline Number of lanes & 3 \\
\hline Lane span & $3.20 \mathrm{~m}$ \\
\hline Number of directions & 2 \\
\hline Traffic island & $9.50 \mathrm{~m}$ \\
\hline Length & $2.10 \mathrm{~km}$ \\
\hline Number of intersections & 4 \\
\hline
\end{tabular}

Source: Resmi Gazete 2008.

The beginning of Nalcaci Street (south) is Vatan Street and the end (north) is Yeni Istanbul Street. There are 4 intersections between the beginning and ending of Nalcaci Street. These junctions are shown in Figure 4. 
Figure 4. Intersections in Nalcaci Street


3rd Intersection

4th Intersection

Existing Situation and Evaluation of the Current Situation in terms of Noise of the Study Area

The criterion of "Discomfort" has been established to determine the extent to which the physical characteristics of the noise and subjective factors have been assessed, the influence of the individual and the society. Evaluations made to identify the physical characteristics of the noise and to determine the shape and size of the effects are gathered under two main headings as measurement and estimation methods. The measurement methods from these evaluations include the process of making traffic noise records for the determined traffic conditions, using the appropriate measurement techniques in the course of a specified period, inspecting the changes according to time during this period, making analyzes, and assessing them with the standardized le vels accepted for the situation.

Noise, being physically unstable and physiologically disturbing and defined as "undesired sound", arises in two different conditions as indoor environment and noise caused by an external environment. Nalcaci St is one of the major sources of noise in the context of externally induced noise. At the same time, there are many buildings and areas around the Nalcaci St that cause external noises.

Main sources of noise affecting the formation of large noise pollution in the region are traffic-transport noise, land transportation, industrial noises in the immediate vicinity, and ongoing construction noises.

Table 6. Coordinates of Measurement Stations

\begin{tabular}{|l|c|c|}
\hline \multirow{2}{*}{ Station no } & \multicolumn{2}{|c|}{ Coordinates } \\
\cline { 2 - 3 } & $\mathrm{X}$ & $\mathrm{Y}$ \\
\hline 1 & 36454898 & 4192845 \\
\hline 2 & 36454917 & 4192331 \\
\hline 3 & 36454915 & 4192422 \\
\hline 4 & 36455111 & 4192768 \\
\hline 5 & 36455106 & 4192769 \\
\hline 6 & 36456904 & 4208899 \\
\hline 7 & 36455327 & 4193164 \\
\hline 8 & 36455395 & 4193276 \\
\hline
\end{tabular}




\begin{tabular}{|l|l|l|}
\hline 9 & 36455556 & 4193398 \\
\hline 10 & 36455547 & 4193480 \\
\hline 11 & 36455636 & 4193538 \\
\hline 12 & 36455019 & 7192641 \\
\hline 13 & 36455546 & 4193481 \\
\hline 14 & 36455795 & 4193921 \\
\hline
\end{tabular}

Figure 5. Locations of 14 Measurement Points on Satellite Photographs

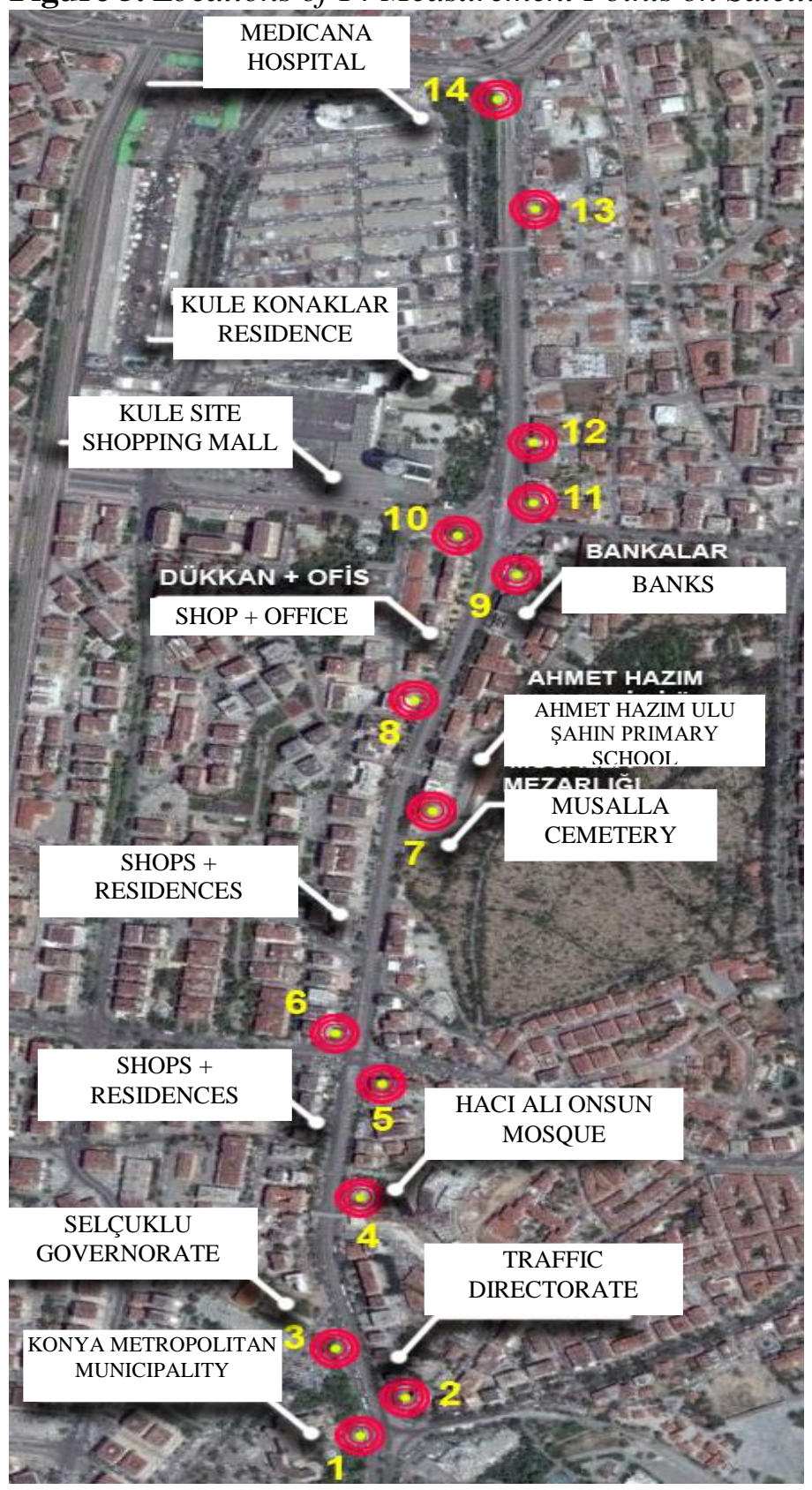




\section{Traffic Noise Measurement Stations (Measurement Points) in the Study Area}

In Konya city center, to determine the noise levels caused by traffic in Nalcaci Street, 14 measurement stations were determined near intersections of junctions and connection roads where business places and traffic are concentrated on the street, and especially for buildings with different usage purposes. Coordinates of the measurement stations, where noise measurements were performed, determined using a hand-held GPS receiver of Magellan Explorist 400. The coordinates of determining measurement stations are given in Table 6.

Figure 5 shows the location of the measurement points on Nalcaci Street on satellite photos and the usage areas around these points.

The reasons that the measurement points were selected in hospitals, housing, schools, hotels, and dormitories is to select where the people in the interior should be least affected, as well as areas containing the large number of people working in large numbers.

\section{Performing Traffic Noise Measurements in Nalcaci Street}

In the interior and exterior space measurements, the microphone should be 1.2-1.5 meters above ground (TS 9798 1992). In exterior space measurements, it is recommended to keep the microphone at least 3.5 meters away from the nearest reflective surface, to minimize potential reflection effects. If the purpose is to measure the level of noise a building is subject to, it is recommended to place the microphone at 1 or 2 meters away from the related front of the building (TS 9798 1992). Figure 6 shows microphone location in exterior spaces. While Kaushki et al. (2016) performed measurements at $1.5 \mathrm{~m}$ height, Onuu and Leong performed theirs at $1.2 \mathrm{~m}$ height (Sandberg 2003, Baaj et al. 2001). Dursun and Özdemir (1999) performed their measurements at ear level $(165-180 \mathrm{~cm}$ from above the ground) (Kalıpc1 2007).

Figure 6. Location of Point Measurement

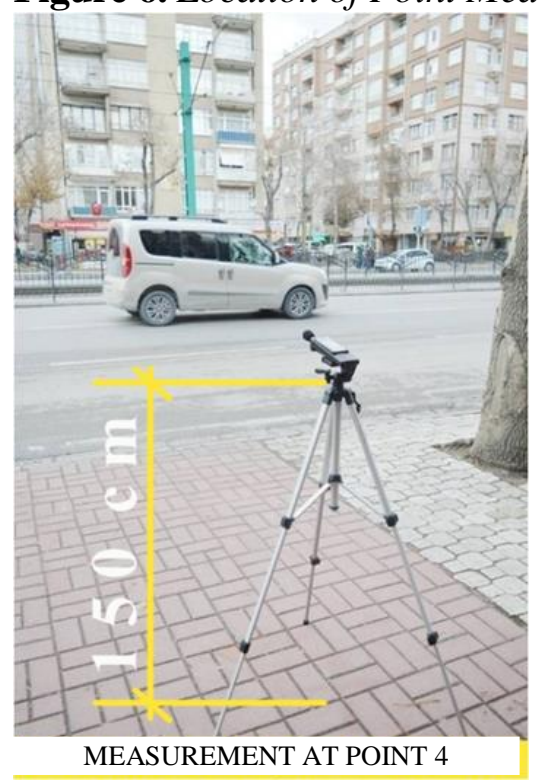


Noise measurements were made with the Testo 815 brand noise meter on December 14, 2015 (at the measuring point) at the 14 measurement stations whose coordinates were taken. The measurements were made at the location shown in Figure 6 at a distance of $2.00 \mathrm{~m}$ behind the roadside edges of the pavement at the noise level or the edge of the junction and at a height of $1.5 \mathrm{~m}$ above the ground and in the absence of precipitation.

On Nalcaci Street, evening measurements were made between 08.00-09.30 hours in the morning, between 12.00-13.30 noon, between 17.00-18.30 hours, during weekdays where the noise of motor vehicles is intense. Seven measurements were made at one measurement station in the morning, noon and evening, and 21 measurements were made at each measurement station in total.

\section{Results and Discussion}

\section{Traffic Noise Measurement Results in Nalcaci Street}

Measurement times and values for traffic noise in Nalcaci Street, where the field study was performed, are given in Table 7.

Table 7. Nalcaci Street, Traffic Noise Measurement Values

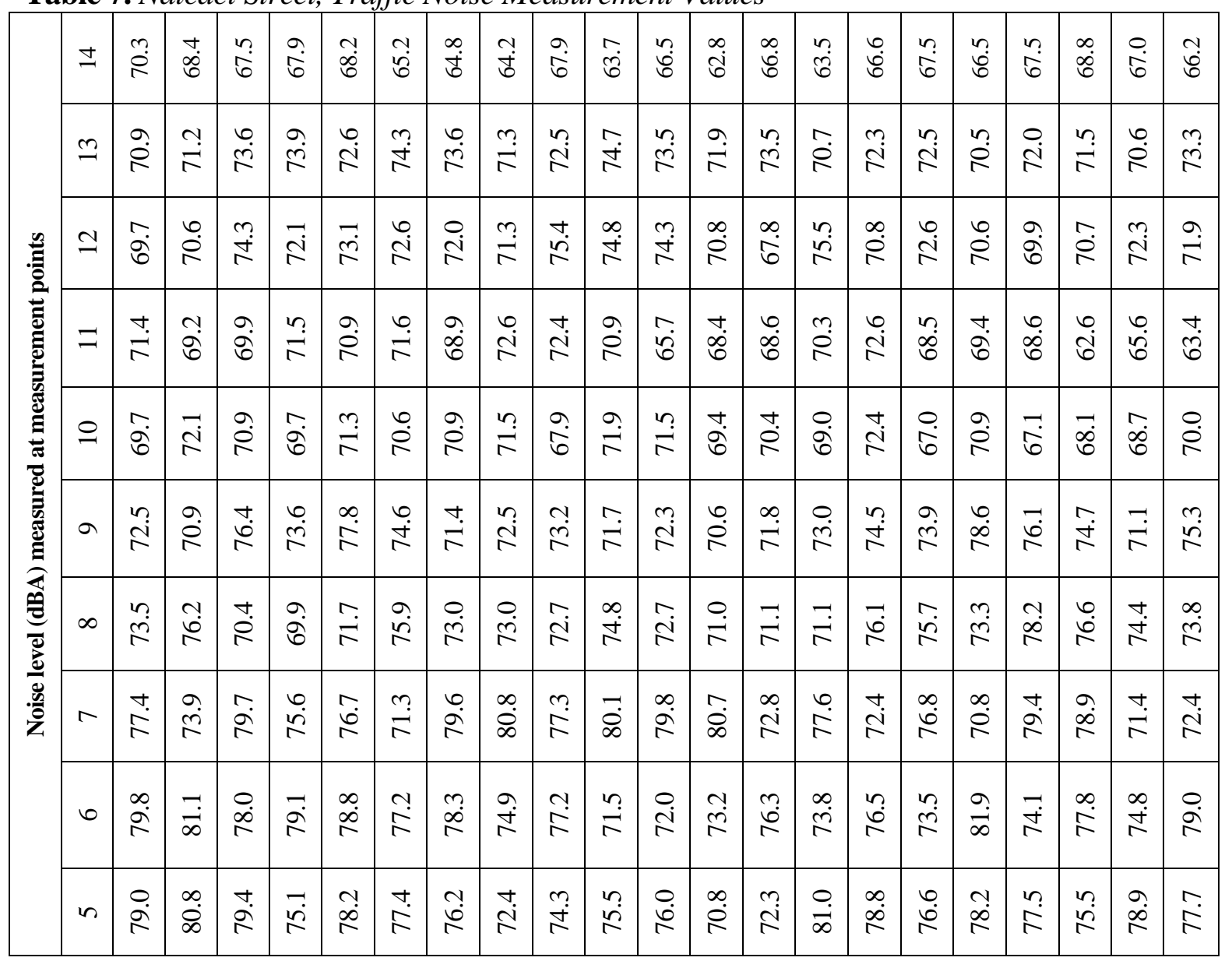




\begin{tabular}{|c|c|c|c|c|c|c|c|c|c|c|c|c|c|c|c|c|c|c|c|c|c|}
\hline$\nabla$ & $\stackrel{2}{\circ}$ & $\stackrel{\infty}{\infty}$ & $\stackrel{\sim}{\infty}$ & $\stackrel{r}{r}$ & $\stackrel{\infty}{\infty}$ & $\stackrel{n}{n}$ & ఠิ & $\stackrel{+}{\infty}$ & $\vec{\infty}$ & $\stackrel{n}{\infty}$ & & $\underset{\infty}{\stackrel{\infty}{\sim}}$ &  & 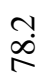 & $\begin{array}{l}\infty \\
\infty \\
\infty\end{array}$ & $\stackrel{m}{2}$ & $\stackrel{\infty}{\stackrel{n}{r}}$ & $\stackrel{n}{2}$ & $\stackrel{\sim}{\infty}$ & $\underset{\bullet}{+}$ & $\begin{array}{l}0 \\
\stackrel{\infty}{\infty}\end{array}$ \\
\hline$m$ & $\ddot{\infty}$ & $\overrightarrow{2}$ & $\stackrel{2}{2}$ & $\stackrel{\infty}{\infty}$ & $\stackrel{\infty}{\infty}$ & $\stackrel{n}{2}$ & $\stackrel{\infty}{\stackrel{\infty}{\curvearrowright}}$ & $\stackrel{2}{2}$ & $\stackrel{\nabla}{\infty}$ & $\stackrel{+}{\stackrel{+}{N}}$ & $\stackrel{\square}{\infty}$ & $\frac{\sim}{\infty}$ & $\ddot{\infty}$ & $\stackrel{0}{2}$ & $\begin{array}{l}0 \\
\dot{\mathbb{T}}\end{array}$ & $\stackrel{ }{n}$ & $\stackrel{\sim}{n}$ & $\hat{\imath}$ & $\stackrel{a}{\infty}$ & فำ & $\underset{\sim}{-\infty}$ \\
\hline$N$ & $\stackrel{\curvearrowright}{尺}$ & $\stackrel{2}{2}$ & $\vec{\infty}$ & $\underset{⿱}{\stackrel{+}{*}}$ & $\stackrel{⿱}{\mathbb{N}}$ & $\stackrel{0}{\circ}$ & $\stackrel{n}{\mathbb{N}}$ & $\stackrel{\circ}{\stackrel{0}{1}}$ & $\hat{\sigma}$ & $\stackrel{9}{R}$ & $\stackrel{0}{\infty}$ & ֶָ & $\stackrel{\infty}{\curvearrowright}$ & $\stackrel{m}{n}$ & $\begin{array}{l}0 \\
\stackrel{2}{r}\end{array}$ & $\underset{\sigma}{0}$ & $\stackrel{\sim}{\infty}$ & $\vec{\infty}$ & $\stackrel{\sim}{\stackrel{N}{*}}$ & $\vec{n}$ & $\begin{array}{l}\infty \\
\infty \\
\infty\end{array}$ \\
\hline- & $\vec{\infty}$ & $\stackrel{0}{\sim}$ & $\underset{i}{\stackrel{0}{r}}$ & $\stackrel{\circ}{\stackrel{+}{r}}$ & $\stackrel{n}{\infty}$ & $\begin{array}{l}\stackrel{0}{\infty} \\
\stackrel{\infty}{\alpha}\end{array}$ & $\begin{array}{l}\infty \\
\infty \\
\infty\end{array}$ & $\frac{0}{\infty}$ &  & & $\underset{\infty}{\stackrel{\infty}{r}}$ & $\begin{array}{l}\infty \\
\infty \\
\infty\end{array}$ & $\tilde{\infty}$ & $\begin{array}{l}\infty \\
\infty \\
\infty\end{array}$ & $\begin{array}{l}0 \\
0 \\
0\end{array}$ & $\stackrel{n}{2}$ & $\underset{\sim}{*}$ & $\stackrel{9}{N}$ & $\stackrel{n}{N}$ & $\vec{n}$ & $\underset{\infty}{\infty}$ \\
\hline  & $\begin{array}{l}8 \\
0 \\
0 \\
0\end{array}$ & $\frac{n}{\infty}$ & $\begin{array}{l}\text { O } \\
\infty \\
\infty\end{array}$ & $\begin{array}{l}\mathscr{n} \\
\stackrel{0}{0} \\
\infty\end{array}$ & $\begin{array}{l}8 \\
8 \\
8\end{array}$ & $\frac{n}{8}$ & $\begin{array}{l}\text { ஜ̊ } \\
\text { gి }\end{array}$ & $\begin{array}{l}8 \\
\text { i }\end{array}$ & $\frac{n}{c}$ & 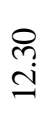 & 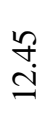 & $\begin{array}{l}8 \\
\dot{2}\end{array}$ & $\frac{n}{n}$ & $\begin{array}{l}\stackrel{\oplus}{\sim} \\
\text { ஸे }\end{array}$ & $\begin{array}{l}8 \\
\\
\end{array}$ & $\frac{n}{\check{I}}$ & 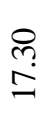 & $\begin{array}{l}\stackrel{n}{5} \\
\stackrel{5}{-}\end{array}$ & $\begin{array}{l}8 \\
\infty \\
\infty\end{array}$ & $\stackrel{n}{\infty}$ &  \\
\hline 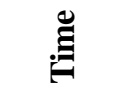 & \multicolumn{7}{|c|}{ MORNING (08.00-09.30) } & \multicolumn{7}{|c|}{ NOON (12.00-13.30) } & \multicolumn{7}{|c|}{ EVENING (17.00-18.30) } \\
\hline
\end{tabular}

\section{Evaluating Measurement Values in terms of Affected Spaces and Legislation}

As evaluation criteria, the interior space noise limit values are given in Table 8 below, which are presented in line (a) of Article 20 published in the "Directive on Evaluating and Management of Ambient Noise", prepared by the Ministry of Environment and Forestry, published in the Official Gazette dated 01.07.2005 and no 25862 .

Table 8. Interior Noise Level Limit Values

\begin{tabular}{|c|c|c|c|}
\hline \multicolumn{2}{|r|}{ Usage Area } & $\mathrm{L}_{\mathrm{eq}}(\mathrm{dBA})$ & Time $(\mathrm{h})$ \\
\hline \multirow[t]{2}{*}{ Health Facilities } & $\begin{array}{l}\text { Inpatient treatment institution(s), dispensary, } \\
\text { polyclinic, nursing homes and rest homes }\end{array}$ & 35 & Continuous \\
\hline & Resting and treatment rooms & 25 & Continuous \\
\hline $\begin{array}{l}\text { Education } \\
\text { Facility Areas }\end{array}$ & $\begin{array}{l}\text { School classes, interiors of pre-school } \\
\text { buildings, laboratories, private education } \\
\text { facilities, }\end{array}$ & 35 & During class \\
\hline \multirow{2}{*}{$\begin{array}{l}\text { Tourism } \\
\text { Accommodation } \\
\text { Areas }\end{array}$} & $\begin{array}{l}\text { Hotels, holiday villages, guesthouses, and } \\
\text { bedrooms }\end{array}$ & 30 & During sleep \\
\hline & Restaurant in the rest area & 35 & During meals \\
\hline \multirow{5}{*}{$\begin{array}{l}\text { Commercial } \\
\text { buildings }\end{array}$} & Large office & 35 & During work \\
\hline & Meeting halls & 35 & During work \\
\hline & Private office (applied) & 50 & During work \\
\hline & Work centers, shops, etc. & 60 & During work \\
\hline & Lunchrooms & 45 & During work \\
\hline \multirow{2}{*}{ State Offices } & Offices & 45 & During work \\
\hline & Meeting halls & 35 & During work \\
\hline \multirow{3}{*}{ Housing Areas } & Bedrooms (in the city) & 40 & During night \\
\hline & Living rooms (in the city) & 55 & $\begin{array}{l}\text { Day through } \\
\text { evening }\end{array}$ \\
\hline & $\begin{array}{c}\text { Service areas (kitchen) (inner-city, upstate, } \\
\text { and city limits) }\end{array}$ & 60 & During activity \\
\hline
\end{tabular}

Source: Wetzel et al.1999. 


\section{Conclusions}

The problem of noise is becoming a growing problem in big cities every day. This problem was determined especially at the Nalcaci Street in Konya city center as a result of noise measurements performed at morning, noon, and evening hours. Motor vehicles especially stop and get up at roundabouts, stopping to get passengers on the road, and sounding horns are the main reasons that increase the level of noise on the route.

Figure 7. Average Chart of Measurements Made at Morning, Noon, and Evening Time of All Measurement Points

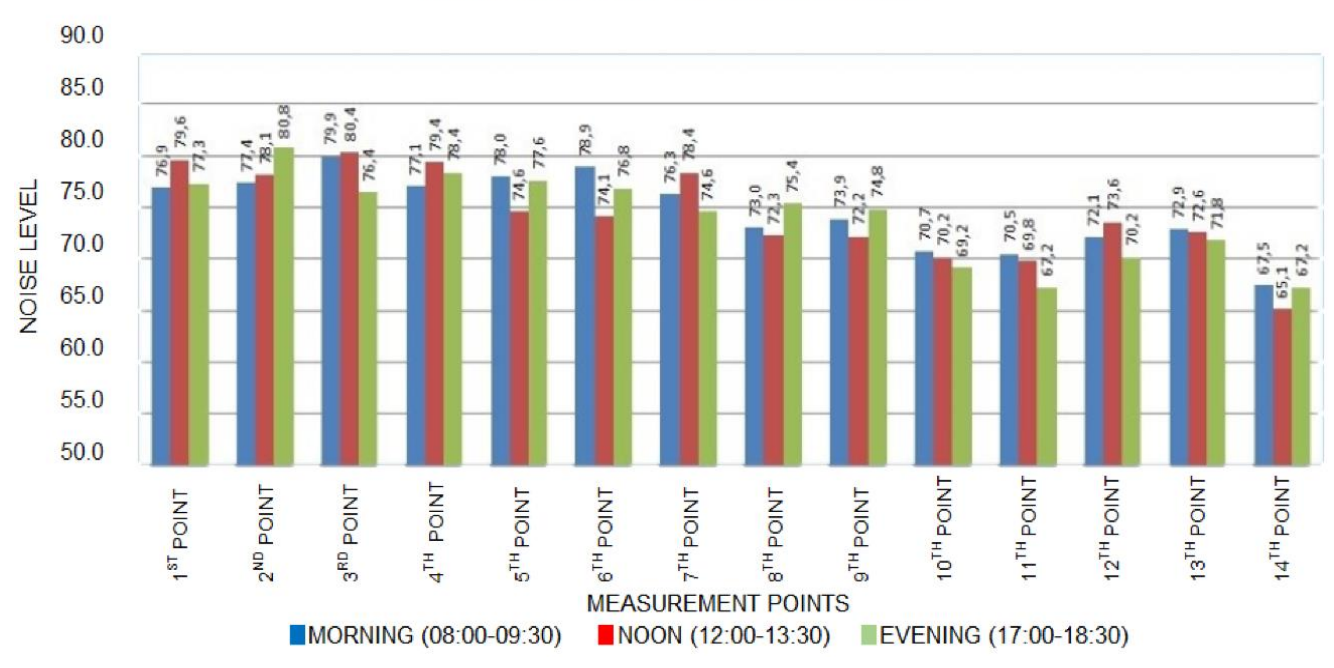

When general averages of the values measured at measurement stations in the morning, noon, and evening were taken and shown on graphics, it was understood that there is a decrease in noise levels from the southern part of Nalcaci Street towards the north, which is from point 1 towards point 14 (Figure 7). Among all the measurement points, the lowest measurement was at point 14 at noon with $64.1 \mathrm{dBA}$, and the highest measurement was at point 2 with $80.8 \mathrm{dBA}$. The reason for the decrease in intensity towards point 14 is the underground passage, which a lot of vehicles go through.

All measurement points on the street were compared to the acceptable noise levels given in the regulation, assuming that the building gaps, such as windows and doors in the building envelope, are open. The values measured in all of the measurement stations were determined to be exceeding the limit values given in the Noise Control Regulation by 10-15 dBA. This result has negative effects on the health of the people affected by this noise in the environment and affects the indoor welfare and comfort in a negative direction. Such noise levels necessitate certain precautions. 


\section{Suggestions}

It is a requirement that can be accepted by all, to reduce noise to acceptable levels, which noise causes human environments to lose their silence, threatens human health, and produces results that cannot be cured and treated. There are some precautions to decrease noise. These are:

1- Precautions for vehicles

1a- Vehicle speed factor: Reducing the speed of the vehicles both reduces the noise level and provides noise safety.

1b-Vehicle maintenance factor: Reparation and maintenance work on motor vehicles, especially checks on exhaust pipes, should be performed at regular intervals and specialists and use of punctured exhaust pipes must be banned.

1c- Vehicle driver factor: Collective taxis should be prevented from sounding horns unnecessarily.

1d- Road sensitivity factor: Heavy vehicles should be removed from noisesensitive areas and alternative roads should be constructed.

2- Road precautions

2a- Road speed breaker factor: It is suggested to remove and reduce the number of speed breakers on the roads since they increase noise.

2b- Road quality factor: It is suggested to manufacture road coating materials using a less rough substance, which will also absorb sounds and minimize reflection.

3- Building precautions

3a- Source-building distance factor: The distance between a noise source and building should be increased.

3b- Building front design factor: Building fronts facing noise sources should be made as short and deaf as possible.

3c- Front sound breaker factor: There should be no protrusions, balconies, etc. on the front that faces a noise source.

3d- Environment-front factor: Openings in silent environments should be as small as possible.

3e- Mass reverberation effect: The masses must be designed to prevent noise from reflecting and increasing.

3f- Importance rating for isolation precautions: In our country, sound isolation is not paid attention to as much as heat isolation. In the buildings exposed to the noise on the street, it is necessary to apply double glazing with noise insulation materials especially on the fronts facing the noise source. However, since the sound insulation materials used in the walls are costly in terms of economy, more economically appropriate measures should be taken.

$3 g$ - Building envelope design factor: Sound insulation should also be added in the production of materials used for exterior walls and heat insulation, and designs should be made to create common solutions. The noisy interior performance of the building envelope, that is, the exterior building elements, is directly related to the external noise level. Therefore, the sound insulation values of the building envelope vary depending on the occupancy - space ratio of the envelope. 
However, it is not possible to perform such a comprehensive evaluation. For this reason, the outer walls with the greatest total surface area in the building envelope are taken into account since they provide a large amount of sound insulation. Sound isolation values for a wall depending on its specifications. To determine the sound insulation value of the building element, generally, the calculation methods are used considering the superficial mass of the material. However, there are numerous examples of wall types that make up a building's envelope. To limit these, we have selected the wall types which are characterized and used widely in the standards produced in our single-layered and double-layered countries which are evaluated only by considering the surface masses. Table 9 gives a comparison of single-layer wall values measured for loss of sound transit (Kurra 2009).

Table 9. A Comparison of Single-Layer Wall Values Measured for Loss of Sound Transit

\begin{tabular}{|l|c|c|c|}
\hline Material & $\begin{array}{c}\text { Dimensions } \\
(\mathrm{cm})\end{array}$ & $\begin{array}{c}\text { Wall thickness (exc. } \\
\text { plaster) }(\mathrm{cm})\end{array}$ & $\begin{array}{c}\text { Sound Transit } \\
\text { Loss }(\mathrm{dB})\end{array}$ \\
\hline Masonry with horizontal openings & $19 \times 13.5 \times 19$ & 19 & 47 \\
\hline Masonry with vertical openings & $19 \times 19 \times 13.5$ & 19 & 49 \\
\hline Filled briquette wall & $20 \times 13.5 \times 39$ & 20 & 47 \\
\hline Pumice concrete block & $19 \times 39 \times 19$ & 19 & 47 \\
\hline Gas concrete block wall & $60 \times 20 \times 25$ & 20 & 46 \\
\hline Concrete wall & - & 20 & 51 \\
\hline Double Wall Envelope & $19 \times 19 \times 13.5$ & 26 & 49 \\
\hline Building Envelope with Curtain Wall & $19 \times 19 \times 13.5$ & 27 & 52 \\
\hline
\end{tabular}

Interior environment noise limit values in Nalcaci Street are given in Table 10 , which is based on the $87.7 \mathrm{~dB}$ value that is the highest noise level acquired in the measurements performed at 14 points.

$$
\Delta \max =87.7 \mathrm{~dB}
$$

Table 10. Comparison of Single-Layer Wall Values, Compared for Sound Transit Loss, based on Noise Levels at Measurement Points

\begin{tabular}{|c|c|c|c|c|c|c|}
\hline & & $\begin{array}{l}\text { Masonry } \\
\text { with } \\
\text { horizontal } \\
\text { openings } \\
(47 \mathrm{~dB})\end{array}$ & $\begin{array}{c}\text { Concrete wall (51 } \\
\text { dB) }\end{array}$ & $\begin{array}{l}\text { Cellular Gas } \\
\text { concrete wall } \\
(46 \mathrm{~dB})\end{array}$ & $\begin{array}{c}\text { Double Wall } \\
\text { Envelope }\end{array}$ & $\begin{array}{c}\text { Building } \\
\text { Envelope } \\
\text { with } \\
\text { Curtain } \\
\text { Wall }\end{array}$ \\
\hline & & $\begin{array}{c}\Delta \max - \\
\Delta \text { brick }=87.7 \\
\mathrm{~dB}-47 \mathrm{~dB} \\
=40.7 \mathrm{~dB}\end{array}$ & $\begin{array}{c}\Delta \max -\Delta \text { concrete } \\
=87.7 \mathrm{~dB}-51 \mathrm{~dB} \\
=36.7 \mathrm{~dB}\end{array}$ & $\begin{array}{c}\Delta \max -\Delta \\
\text { cellular } \\
\text { concrete }= \\
87.7 \mathrm{~dB}-46 \\
\mathrm{~dB}=41.7 \\
\mathrm{~dB}\end{array}$ & $\begin{array}{l}\Delta \text { max }-\Delta \text { brick } \\
=87.7 \mathrm{~dB}-49 \\
\mathrm{~dB}=38.7 \mathrm{~dB}\end{array}$ & $\begin{array}{c}\Delta \max -\Delta \\
\text { curtain } \\
\text { wall = } \\
87.7 \mathrm{~dB}- \\
52 \mathrm{~dB} \\
=34.7 \mathrm{~dB}\end{array}$ \\
\hline Places & $\begin{array}{c}\text { Interior } \\
\text { noise level } \\
\text { limit } \\
\text { values }\end{array}$ & & & & & \\
\hline Hotel & 30 & -10.7 & -6.7 & -11.7 & -8.7 & -4.7 \\
\hline Dormitory & 30 & -10.7 & -6.7 & -11.7 & -8.7 & -4.7 \\
\hline School & 35 & -5.7 & -1.7 & -6.7 & -3.7 & +1.3 \\
\hline Hospital & 35 & -5.7 & -1.7 & -6.7 & -3.7 & +1.3 \\
\hline
\end{tabular}




\begin{tabular}{|c|c|c|c|c|c|c|}
\hline Office & 35 & -5.7 & -1.7 & -6.7 & -3.7 & +1.3 \\
\hline $\begin{array}{c}\text { Residential } \\
\text { (Bedroom) }\end{array}$ & 40 & 0.7 & +3.3 & -1.7 & +1.3 & +5.3 \\
\hline $\begin{array}{c}\text { Residential } \\
\text { (Living } \\
\text { Room) }\end{array}$ & 55 & +14.3 & +18.3 & +13.7 & +16.3 & +20.3 \\
\hline Shop & 60 & 20.7 & +23.3 & +18.7 & +21.3 & +25.3 \\
\hline
\end{tabular}

3h- In the schools, hospitals, and office buildings with sensitive usage areas, the isolation of the windows should be done very well and the effect of external noise should be minimized and the application of double glazing should be increased.

\section{Measures to be Taken Close to the Study Area}

4a- Artificial barriers applied to reduce noise on highways and roads outside the city center are not recommended because there is not enough application area in the city and it does not appear aesthetic.

$4 \mathrm{~b}$ - Natural barrier application instead of artificial barrier application is the most suitable noise reduction measure for Nalcaci Street. Better results can be obtained if the herbal materials to be used in noise prevention are selected from a variety of common, broad-leaved, thick, and feathered leaves. Thus, there is a chance that the plants can suppress noise to a certain level. In road tree planting studies, the selected plants which are suitable for the purpose must be connected to the environment with their aesthetic and physiological characteristics.

Leaf-bearing plants should have short leaf-bearing periods and they should remain green and fruitful in all seasons. In the selection of species, consideration should be given to the relationship among road class, the use of the surrounding area, plant-road, structure and infrastructure, and the selected species should be suitable for road and environmental structures. Planting is not only effective in reducing noise, it also reduces the effects of sun and rain on the drivers, as it reduces dust generated during navigation. Not only roadsides but also refuges should be planted. Because planting can both serve human beings functionally and aesthetically. Approximate sound minimization values are given in the Hungarian Traffic Noise Prediction Model, based on various tree types. Shrubbery group provides the most effective noise suppression. This suppression is observed as between 9-10 dBA at 60 meters (Beranek 1974).

Pinewood: $0.1-0.15 \mathrm{dBA} / \mathrm{m}(1-1.5 \mathrm{dBA}$ reduction at 10 meters $)$

Broad-leaved trees: $0.08-0.1 \mathrm{dBA} / \mathrm{m}(0.8-1 \mathrm{dBA}$ reduction at 10 meters $)$

Shrubbery: $0.15-0.17 \mathrm{dBA} / \mathrm{m}(1.5-1.7 \mathrm{dBA}$ reduction at 10 meters $)$

\section{References}

Akgüngör P, Demirel A (2003) Klrıkkale ilinde trafik Kaynaklı gürültü haritalart. (TrafficOriginated noise maps in kırıkkale province). Ankara: IV. Ulaşım ve Trafik KongresiSergisi Bildiriler Kitabı. 
Alexandre A (1975) Road traffic noise. New York: Wiley.

Aydın ME (2004) Konya şehri taşıt trafiği gürültü seviyeleri haritasının GIS ve GPS teknolojileri kullanılarak elde edilmesi. (Obtaining the Konya city vehicle traffic noise levels map using GIS and GPS technologies). Journal of the Engineering and Architecture Faculty of Selcuk University 20(2): 7-18.

Baaj MH, El-Fadel M, Shazbak SM, Saliby E (2001) Modeling noise at elevated highways in urban areas: a practical application. Journal of Urban Planning and Development 127(4): 169-180.

Bay F, Güney A (1998) Lastik-Yol gürültüsü. (Tire-Road noise). Antalya: 4. Ulusal Akustik Kongresi, 15-173.

Beranek LL (1974) Noise reduction. McGraw-Hill Book Co. Inc.

Can H, Özdemir T, Arık A (2000) illerde gürültü haritalarl ve Balıkesir örneği. (Noise maps in provinces and the case of Balıkesir). Antalya: TMMOB Makine Mühendisleri Odası 1. Kentiçi Ulaşım ve Trafik Sempozyumu Bildiriler Kitab1, 74-79.

Cho DS, Mun S (2006) Determination of the sound power level emitted by various vehicles using a novel testing method. Applied Acoustics 69(3): 185-195.

Cho DS, Mun S (2008) Study to analyze the effects of vehicles and pavement surface types on noise. Applied Acoustics 69(9): 833-843.

Demirkale SY (1996). The measurement and analysis of the noise caused by run-up operations at Atatürk airport. Architectural Science Review 39(1): 39-47.

Doelle LL (1972) Environmental acoustics. McGraw-Hill Book Co. Inc.

Dursun Ş, Özdemir C (1999) Konya il merkezinde gürültü kirliliği haritasının hazırlanmasi. (Preparation of noise pollution map in Konya city center). Konya: Proje No: 97-081, 4-24.

European Asphalt Pavement Association - EAPA (2007) Abatement of traffic noise the arguments for asphalt. Belgium: EAPA.

EU Green Paper (1996) Future noise policy. Brussels: Commission of the European Communities.

Freitas E, Mendonça C, Santos JA, Murteira C (2012) Traffic noise abatement: how different pavements, vehicle speeds, and traffic densities affect annoyance levels. Transportation Research Part D 17(4): 321-326.

Güremen L, Çelik CT (2003) Niğde merkezinde yol trafik gürültüsü ve gürültüden Etkilenme seviyeleri. (Road traffic noise and noise affected levels in Niğde center). Niğde: Niğde Üniversitesi Mühendislik Bilimleri Dergisi Cilt 7.

Harris R, Cohn L, Knudson S (2000) Evaluation of the federal highway administration's traffic noise model. Journal of Transportation Engineering-ASCE 126(6): 513-520.

Ho KY, Hung WT, Fai NG, Lam YK, Leung R, Kamc E (2013) The effects of the road surface and tire deterioration on tire/road noise emission. Applied Acoustics 74(7): 921-925.

Kalıpcı E (2007) Giresun il merkezinde gürültü kirliliği ölçümü ve haritasının hazırlanmasl. (Measurement and mapping of noise pollution in Giresun city center). Yüksek Lisans Tezi. Konya: Selçuk Üniversitesi Fen Bilimleri Enstitüsü.

Kaushik A, Al Horr Y, Arif M, Mazroei A, Katafygiotou M, Elsarrag E (2016) Occupant productivity and office indoor environment quality: a review of the literature. Build Environment 105(Aug): 369-389.

Ko JH, Chang S, Lee BC (2011) Noise impact assessment by utilizing noise map and GIS: a case study in the city of Chungju, Republic of Korea. Applied Acoustics 72(8): 544-550.

Konya Büyükşehir Belediyesi - Konya Metropolitan Municipality (2013) Konya Büyükşehir Belediyesi 2013 yılı saat dilimlerine göre trafik dağıllmı ve yol özellikleri 
verileri. (Konya Metropolitan Municipality traffic distribution and road characteristics data according to 2013 time zones). Konya Büyükşehir Belediyesi.

Kurra S (1991) İstanbul'un çevre sorunları ve çözüm yolları. (Istanbul's environmental problems and solutions). İstanbul Ticaret Odası 11: 266-297.

Kurra S (1997) Çevre gürülttüsü kirliliği ve kontrolü. (Environmental noise pollution and control). In Gürültü ile Savaşım Sempozyumu, YTÜ, Istanbul, 31-40.

Kurra S (2000) Köprüler, yollar ve çevre kirliligi. (Bridges, roads and environmental pollution). In Ulusal Akustik Kongresi, Istanbul, 95-103, 2000.

Kurra S (2009) Çevre gürültüsü ve yönetimi. (Environmental noise and management). In İstanbul Bahçeşehir Üniversitesi Yayınları, İstanbul, 55-460.

Kurra S, Taner N, Altay A, Samsunlu A (1993) Çevre gürültüsü analiz ve değerlendirme sistemleri. (Environmental noise analysis and evaluation systems). İstanbul: Tübitak, Kimyasal Teknolojiler ve Çevre Araştırma Grubu.

Ledee FA, Pichaud Y (2007) Temperature effect on tire-road noise. Applied Acoustics 68(1): $1-16$.

Li B, Tao S, Dawson RW, Cao J, Lam K (2001) A GIS-based road traffic noise. Applied Acoustics 63(6): 679-691.

Naish D (2010) A method of developing regional road traffic noise management strategies. Applied Acoustics 71(7): 640-652.

Nas B, Berktay A (2004) Konya kenti yol trafik gürültüsü seviyeleri'nin cografi bilgi sistemleri (CBS) ile görüntülenmesi. (Visualization of Konya city road traffic noise levels with geographical information systems (GIS)). Konya: 3. Cografi Bilgi Sistemleri Bilisim Günleri.

Organisation for Economic Co-operation and Development - OECD (1986) Fight noise. Paris: OECD.

Özyonar F, Peker I (2008) Sivas kent merkezindeki çevresel gürültü kirliliğinin arastırlmasl. (Investigation of environmental noise pollution in Sivas city center). Ekoloji Dergisi 18(69): 70-75.

Pakman B (1990) Causes of traffic noise and measures that can be taken. Karayollarl Vakfi Dergisi 3(17): 27-31.

Praticòa FG, Lédéeb FA (2012) Trends and issues in mitigating traffic noise through quiet pavements. Procedia - Social and Behavioral Sciences 53(Oct): 203-212.

Qadis SA, Alhory A (2007) Statistical models for traffic noise at signalized intersections. Building and Environment 42(8): 2939-2948.

Resmi Gazete - Official Newspaper (2008) Çevresel gürültünün degerlendirilmesi ve yönetimi yönetmeligi. (Environmental noise assessment and management regulation). Resmi Gazete, Sayı: 26809.

Sandberg U (2003) The multi-coincidence peak around $1000 \mathrm{~Hz}$ in Tyre/Road noise spectra. Naples: Internoise.

Sandberg U, Ejsmont J (2002) Tyre/Road noise reference book. Informex. SE-59040 Kisa, Sweden: www.informex.info.

Tang KS, Tong KK (2004) Estimating traffic noise for inclined roads with freely flowing traffic. Applied Acoustics 65(2): 171-181.

TS 9798 (1992) Akustik-çevre gürültüsünün tanımlanması ve ölçülmesi kısım 2-arazi kullanımında meydana gelen gürültülerle ilgili verilerin elde edilmesi. (Identification and measurement of acoustic-environmental noise part 2-Obtaining data on noise occurring in land use). Retrieved from: https://intweb.tse.org.tr/Standard/Standard/ Standard.aspx?08111805111510805110411911010405504710510212008811104311 3104073097068056075104103107076073117098. 
Wetzel E, Nicolas J, Andre PH, Boreux J (1999) Modelling the propagation pathway of street-traffic noise: practical comparison of German guidelines and real-world measurements. Applied Acoustics 57(2): 97-107.

Zannin PH, Ferreira AM, Szeremetta B (2006) Evaluation of noise pollution in urban parks. Environmental Monitoring and Assessment 118(Jul): 423-433. 